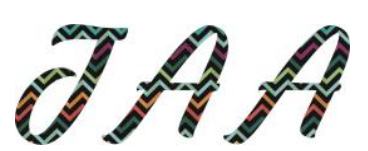

Vol. 6, No. 1, Oktober 2021

\title{
REAKSI PASAR SAHAM PERUSAHAAN FARMASI SEBELUM DAN SESUDAH PENGUMUMAN COVID-19 DI INDONESIA
}

\author{
Kartika Pradana Suryatimur \\ Universitas Tidar \\ kpsuryatimur@untidar.ac.id \\ Nibras Anny Khabibah \\ Universitas Tidar \\ nibras@untidar.ac.id
}

Article History:

Received: 24 Agustus 2021

Revised: 3 September 2021

Accepted: 3 September 2021

DOI: $10.29303 / j a a . v 6 i 1.112$
Abstract: activities that have an impact on stock market conditions in the world, including Indonesia. This study identified differences in stock prices and stock trading volumes (TVA) of companies in the pharmaceutical sector before and after the announcement of the first COVID-19 case in Indonesia. The sample used is 10 pharmaceutical sector companies listed on the Indonesia Stock Exchange (IDX). The method used in this research is an event study using paired sample $t$-test. Based on the test results, it is known that there is a difference in prices before and after the announcement of the first COVID-19 case in Indonesia on the 5th and 7th day, but there was no difference in trading volume activity testing.

Abstrak: Pandemi covid 19 membawa dampak pada aktivitas social dan ekonomi yang memberikan dampak pada kondisi pasar saham di dunia termasuk Indonesia. Penelitian ini mengidentifikasi adanya perbedaan harga saham dan volume perdagangan saham (TVA) perusahaan pada sektor farmasi antara sebelum dan sesudah pengumuman kasus positif covid19 pertama di Indonesia. Penelitian ini menggunakan sampel 10 perusahaan sektor farmasi yang terdaftar pada Bursa Efek Indonesia (IDX). Metode yang digunakan dalam penelitian ini adalah event study dengan menggunkan pengujian uji beda sampel berpasangan (paired sample $t$ test). Berdasarkan hasil pengujian diketahui terdapat adanya perbedaan harga sebelum dan sesudah pengumuman kasus covid 19 pertama di Indonesia pada hari ke 5 dan ke7, namun tidak terdapat perbedaan pada pengujian volume perdagangan.

Keyword : The COVID-19 pandemic has had an impact on social and economic . Kata kunci : covid19; trading volume activity; stock price 


\section{PENDAHULUAN}

Covid-19 pertama kali dilaporkan muncul di China, virus tersebut dikaitkan dengan salah satu pasar makanan di Wuhan provinsi Hubei. Orang yang tertular Covid-19 diketahui memiliki gejala pneumonia dan seperti flu biasa. (Sohrabi, 2020) Kasus kematian pertama karena Covid-19 ini dilaporkan terjadi pada 11 Januari 2020 (Yang et al, 2020). Pemerintah setempat mengeluarkan kebijakan untuk tindakan pengamanan dengan karantina, menutup perbatasan kota-kota besar, dan menahan orang agar tidak keluar rumah untuk mencegah penyebaran Covid-19 (Yang et al., 2020)

Pandemi Covid-19 mempengaruhi iklim investasi dan bisnis di China. Penelitian sebelumnya menunjukkan adanya hubungan negatif antara kasus Covid-19 dengan harga saham seluruh perusahaan di Hang Seng Index dan Shanghai Stock Exchange Composite

Penyebaran Covid-19 yang menjadi pandemi memberikan dampak kuat untuk melemahkan sektor ekonomi sebuah negara. Di negara lain seperti China, lingkungan bisnis dan investasi juga terdampak langsung oleh Covid-19 (Al-Awadhi et al., 2020). Pengumuman konfirmasi kasus Covid-19 di Indonesia oleh Presiden pada tanggal 2 Maret 2020 lalu diyakini berdampak langsung pada kegiatan bisnis sehingga menyebabkan

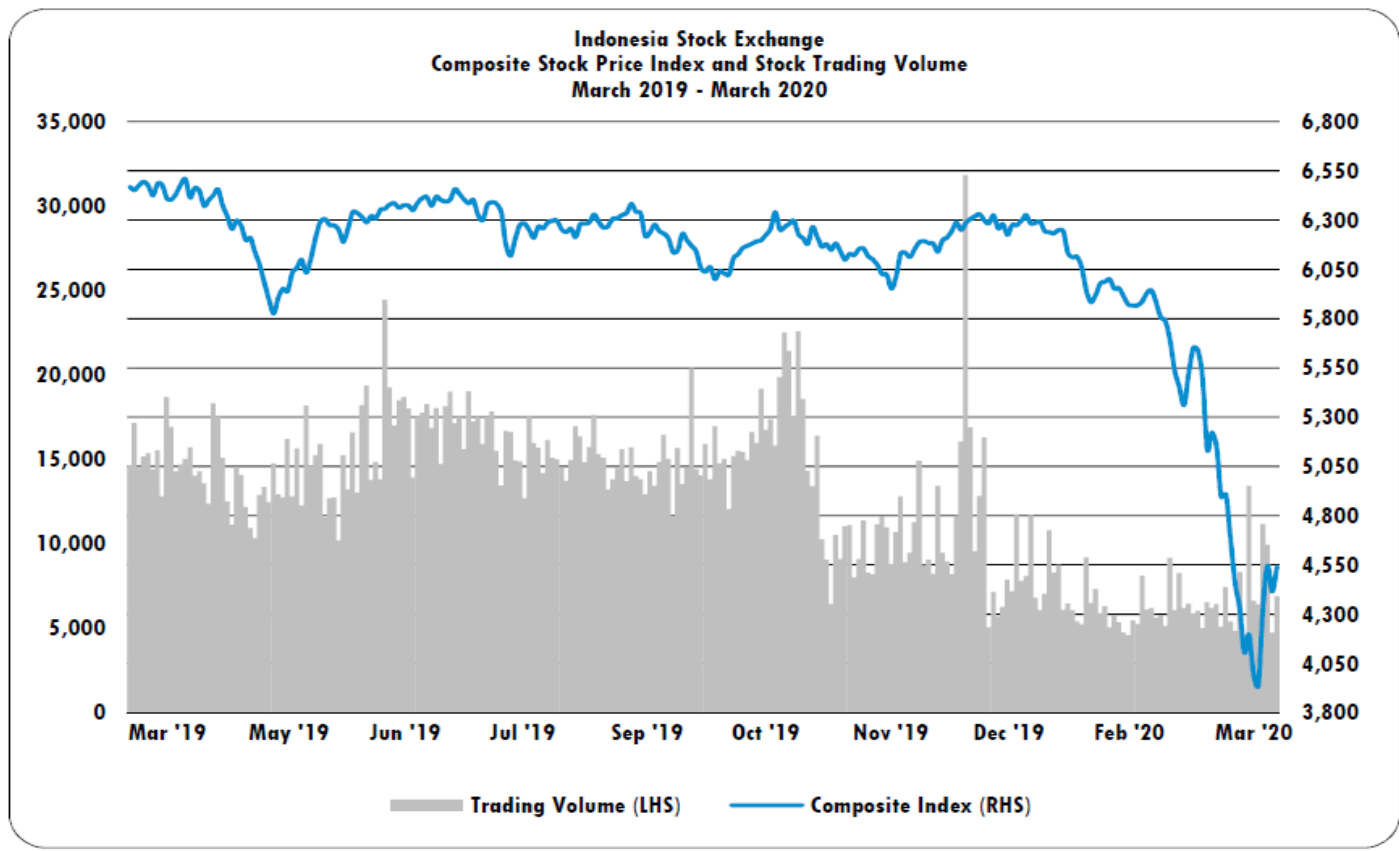

anjloknya IHSG.

Gambar 1. Grafik IHSG dan Volume Pergadangan Saham Maret 2019 - Maret 2020

Sumber : IDX Monthly Statistic March 2020 


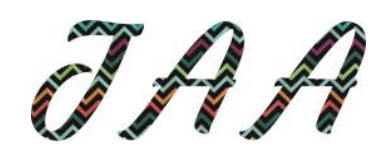

Vol. 6, No. 1, Oktober 2021

Gambar 1 menunjukkan terjadi penurunan IHSG dan volume perdagangan saham yang cukup signifikan jika dibandingkan dengan bulan Maret tahun 2019. Selama bulan Maret 2020 tercatat IHSG terendah berada pada level 3.937,632 yang terjadi pada tanggal 24 Maret 2020, dengan level tertinggi pada level 5.650,136 pada tanggal 4 Maret 2020, dan ditutup pada tanggal 31 Maret 2020 dengan level 4.538,930 (IDX, 2020). Sikap pemerintah dalam menghadapi kasus Covid-19 di Indonesia turut menjadi andil penyebab menurunnya kepercayaan investor. Hal itu menyebabkan terjadinya penarikan dana atas investasi saham dan memindahkan ke instrument investasi lain yang dinilai lebih aman seperti emas.

Telah terjadi volatilitas di pasar saham di seluruh dunia sejak kasus Covid-19 mulai menyebar dan menjadi pandemi. Bahkan sejak wabah flu spanyol yang juga pernah menjadi pandemi tidak memberikan dampak volatilitas pasar seperti yang terjadi saat ini (Baker et al, 2020). Lebih lanjut Baker (2020) mengatakan bahwa pengaruh Covid-19 yang sangat besar terhadap kondisi pasar modal ini terjadi karena virus ini memiliki implikasi yang serius terhadap kesehatan masyarakat luas dan kondisi ekonomi banyak negara. Penelitian Kamaludin et al, 2021 menguji dampak covid 19 terhadap pasar modal dengan membagi tiga fase yaitu beginning (Februari), mid (Maret dan April) dan end period (Mei) di Malaysia, Singapura, Thailand, Indonesia, dan Philippine. Hasilnya menunjukkan bahwa covid 19 berdampak di Malaysia, Singapura, dan Indonesia pada mid periode, sedangkan berdampak di Thailand dan Philippine pada end periode. Penelitian lainnya dilakukan oleh Camba \& Jr, 2020, menguji covid 19 terhadap Philippine Stock Exchanges, Peso Dollar Rate, dan Retail Price of Deisel, hasil penelitian menunjukkan bahwa tingkat infeksi harian covid 19 dapat menggerakkan Philippine Stock Exchanges ke arah negatif.

Terdapat beberapa penelitian yang pernah dilakukan sebelumnya yang bertujuan untuk mendapatkan jawaban keterkaitan antara penyebaran wabah penyakit terhadap kegiatan pada pasar saham. Wabah Severe Acute Respiratory Syndrome (SARS) yang pernah ditetapkan menjadi pandemi terbukti berpengaruh terhadap aktivitas pasar saham (Chen, C. D. et al, 2009). Wabah Ebola Virus Disease (EVD) yang juga pernah menjadi wabah di wilayah negara-negara Afrika terbukti mempengaruhi aliran dana dan return pasar (Funck \& Gutierrez, 2018). Penelitian Al-Awadhi (2020) juga menyatakan bahwa terjadi penurunan return saham di China yang disebabkan oleh peningkatan kasus positif dan jumlah kematian karena covid 19.

Penelitian ini bertujuan untuk mengidentifikasi dampak covid-19 terhadap reaksi harga saham dan volume perdagangan perusahaan farmasi di Bursa Efek Indonesia sebelum dan sesudah pengumuman kasus covid19 pertama masuk di Indonesia. Pada 2 Maret 2020, Presiden Indonesia Joko Widodo mengumumkan kasus pertama covid-19 pertama di Indonesia. Setelah pengumuman itu diikuti dengan IHSG yang merosot, serta diikuti 
melemahnya nilai tukar rupiah. Al-Wadhi (2020) dalam penelitianya menyatakan semua sektor pasar modal di China melemah, namun sektor Teknologi Informasi dan manufaktur kesehatan menunjukan kinerja yang lebih baik di masa pandemic covid-19.

\section{Signaling Theory}

\section{LANDASAN TEORI}

Asimetri informasi disebabkan adanya perbedaan informasi tentang perusahaan antara manajemen dengan pemegang saham. Hal itu memunculkan ide tentang Signaling Theory, dimana manajemen maupun investor diharapkan tidak terjadi ketidaksetaraan informasi, salah satu pihak akan mengirimkan sinyal yang dapat mengungkapkan informasi yang relevan kepada pihak lain. Informasi yang dikeluarkan manajemen merupakan sinyal penting untuk proses pengambilan keputusan. Manajemen berupaya memberikan informasi dengan tujuan meningkatkan harga saham (Ross, 1977).

Signaling Theory seharusnya dapat mengungkapkan informasi yang sebenarnya terjadi dalam proses bisnis perusahaan, baik berupa good news maupunpun badnews. Pihak manajemen diharapkan tidak hanya memberikan informasi yang baik dan menutup informasi yang buruk terhadap investor. Dengan demikian diharapkan tidak ada asimetri informasi yang terjadi antara investor dan manajeman. Pada umunya informasi yang disediakan manajemen berupa laporan keuangan yang mencerminkan kondisi keuangan perusahaan. Laporan keuangan yang baik bagi investor ialah yang menyajikan kondisi keuangan pada periode itu tanpa melebihkan laba dan asset, atau pun mengurangi biaya dan utang.

\section{Efficient Market Hyphotesis}

Sebuah pasar dapat dikatakan efisien apabila terbentuknya harga saham dapat mencerminkan seluruh informasi yang ada, baik informasi akuntansi atau informasi nonnakuntansi. Pasar dikatakan dalam kondisi efisien ketika seluruh investor dapat mendapatkan akses informasi di suatu perusahaan (Fama, 1970). Lebih lanjut Fama (1970) mengatakan bahwa adanya perbedaan kesepakatan yang terjadi antar investor mengenai implikasi informasi yang ada tidak mampu menggambarkan kondisi pasar yang tidak efisien. Akan tetapi hal itu dapat dikecualikan ketika banyak investor yang melakukan evaluasi lebih baik mengenai informasi yang ada dibandingkan dari harga saham.

Berbagai macam informasi mampu mempengaruhi harga saham dapat langsung berpengaruh secara langsung dan tanpa penundaan (Ying et al., 2019). Informasi dapat berkaitan dengan berbagai hal, baik berasal dari dalam perusahaan maupun luar perusahaan. Informasi dari dalam perusahaan seperti pengumuman laba, stock split, atau pengumuman 


\section{DA}

Vol. 6, No. 1, Oktober 2021

pembagian dividen, sedangkan informasi dari luar perusahaan seperti kondisi politik, ekonomi, atau pun social. (Zhang, et al 2016).

\section{Pengembangan Hipotesis: Covid-19 dan Reaksi Harga Saham dan Volume Penjualan Saham Perusahaan Sektor Farmasi}

Covid-19 pada awalnya merupakan krisis regional di negara China Provinsi Hubei, yang kemudian menyebar hingga menjadi pandemi global yang menyebabkan ekuitas jatuh dan volatilitas pasar saham meroket di seluruh dunia. Volatilitas pasar di Amerika mengalami peningkatan yang sangat tinggi dibandingkan pada Oktober 1987 dan Desember 2008. (Baker et al., 2020). Lebih lanjut Baker et al (2020) menyatakan bahwa Covid-19 memiliki kemampuan untuk menyebar dengan sangat mudah, serta jumlah kasus kematian cukup tinggi bagi mereka yang terpapar virus. Pandemic ini memberikan implikasi yang serius bagi kesehatan masyarakat dan tentunya juga bagi kondisi ekonomi.

Covid-19 membawa konsekuensi munculnya kebijakan baru dari otoritas di berbagai wilayah dengan tujuan untuk menahan penyebarannya. Covid-19 serta kebijakan untuk mencegah penyebarannya secara langsung memiliki dampak pada berbagai aspek kehidupan termasuk aktivitas bisnis. Implikasi yang dirasakan adalah social distancing yang memiliki peran besar terjadinya gelombang pemberhentian hubungan kerja (PHK) pada banyak perusahaan. Respon dari kebijakan ini dapat menguatkan kemungkinan untuk terjadi volatilitas pada pasar saham yang belum pernah terjadi sebelumnya (Baldwin, 2020)

Selama masa pandemi Covid-19, secara alamiah ekspektasi pasar saham pada setiap sektor akan memiliki dampak yang berbeda-beda. AlWadhi (2020) telah melakukan penelitian terhadap reaksi pasar pada Shanghai Stock Exchange Composite Index terhadap kasus kematian Covid19 di China dan menemukan ada beberapa sektor yang memiliki dampak berbeda dengan sektor lain. Lebih lanjut Al-Wadhi (2020) menyatakan bahwa terjadi kinerja harga saham yang lebih baik pada sektor teknologi informasi dan manufaktur kesehatan.

Kebijakan yang dibuat untuk merespon pandemic Covid-19 dapat menjelaskan pengaruh Covid-19 terhadap pasar saham (Baker et al., 2020). Pemerintah Indonesia melalui Presiden telah mengumumkan kasus terkonfirmasi positif covid-19 pada 2 Maret 2020 lalu. Informasi tersebut menjadi berita buruk yang memiliki potensi dapat mempengaruhi kondisi ekonomi nasional secara keseluruhan seperti yang sudah terjadi pada banyak negara yang sudah terlebih dulu mengkonfirmasi kasus positif covid-19.

Berita terkait konfirmasi kasus positif pertama di Indonesia memberikan sentimen negatif terhadap kondisi pasar saham. Pemerintah tentunya segera menerapkan kabijakan-kebijakan untuk menekan penyebaran covid-19. Kebijakan yang dikeluarkan pemerintah memberikan 
dampak terhadap proses bisnis banyak perusahaan, yang menyebabkan banyak perusahaan harus menutup usahanya karena dampak dari pandemi yang mulai masuk Indonesia.

Perusahaan farmasi merupakan sektor bisnis yang dianggap dapat bertahan pada masa pandemi covid-19 ini. Perusahaan sektor farmasi memproduksi obat-obatan dan beberapa jenis produk kesehatan lain yang selama pandemi covid-19 produknya banyak diperlukan oleh masyarakat. Dengan demikian perusahaan sektor farmasi akan dapat memiliki peluang berkinerja yang lebih baik dibanding dengan beberapa industri pada sektor lain.

$H_{1}$ : Terdapat perbedaan harga saham perusahaan sektor farmasi di Indonesia sebelum dan sesudah pengumuman kasus Covid-19 terkonfirmasi di Indonesia.

$\mathrm{H}_{2}$ : Terdapat perbedaan volume perdagangan saham perusahaan sektor farmasi di Indonesia sebelum dan sesudah pengumuman kasus Covid-19 terkonfirmasi di Indonesia.

\section{Gambar 2 Kerangka Pemikiran}

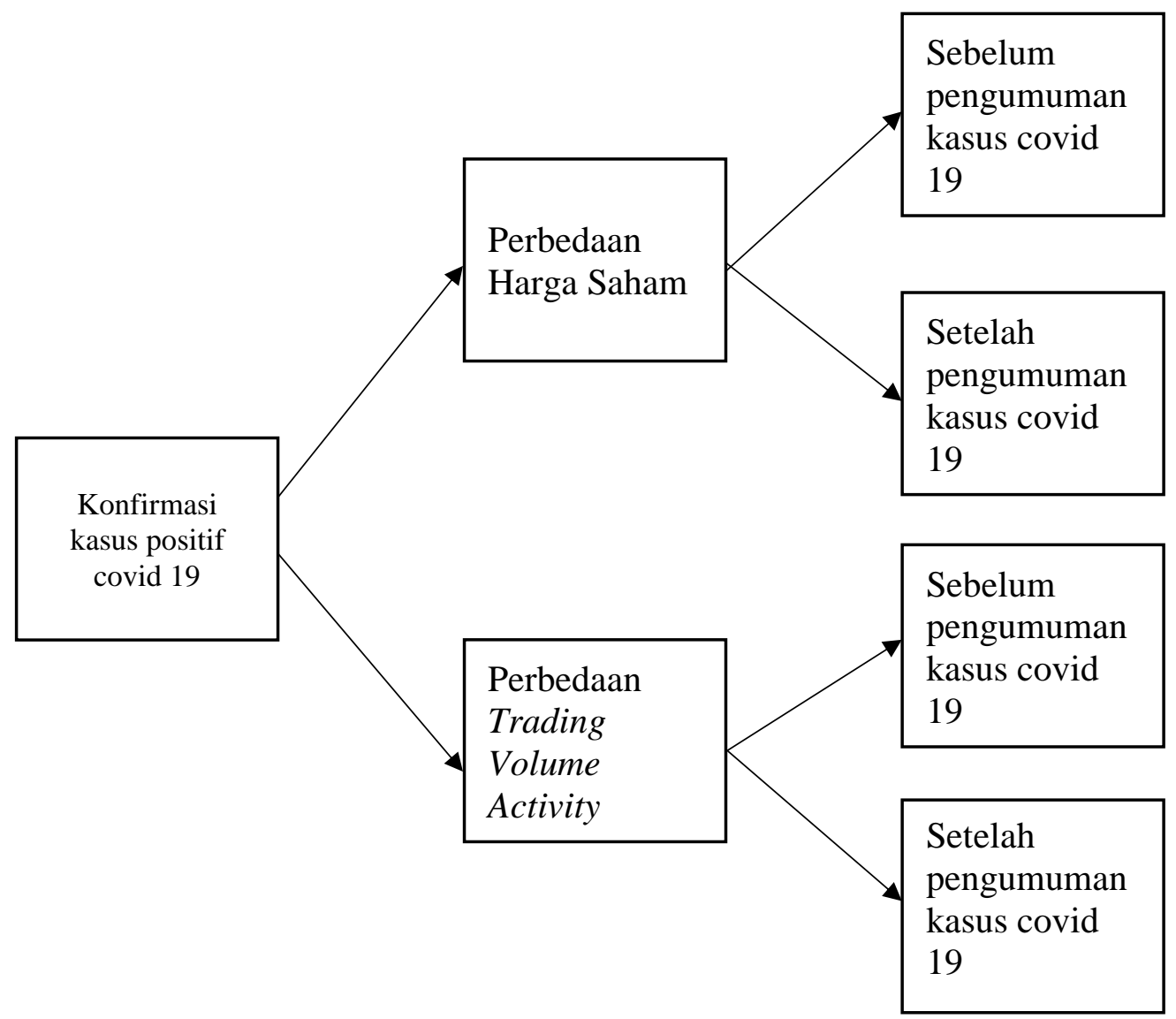




\section{DA}

Vol. 6, No. 1, Oktober 2021

\section{METODE PENELITIAN}

Metode penelitian yang digunakan pada penelitian ini ialah event study. Metode ini memungkinkan untuk mengamati dampak suatu peristiwa terhadap perubahan harga saham dan volume perdagangan saham. Metode event study bertujuan untuk melakukan identifikasi pengaruh informasi adanya pengumuman konfirmasi kasus positif covid 19 terhadap reaksi pasar perusahaan sektor farmasi di Indonesia. Pengujian dilakukan dengan membandingkan harga saham dan volume perdagangan saham sebelum dan sesudah Presiden Indonesia mengumumkan kasus konfirmasi covid 19 pertama kalinya pada 2 Maret 2020. Pengamatan dilakukan pada periode 7 hari sebelum dan 7 hari sesudah terjadinya event. Periode pengamatan dipilih 7 hari sebelum dan 7 sesudah dimaksudkan untuk melihat reaksi investor menanggapi pengumuman kasus covid 19 pertama di Indonesia. Periode amatan ditentukan 7 hari sebelum dan 7 hari sesudah dengan tujuan agar meminimalkan adanya kondisi lain yang dapat mempengaruhi reaksi pasar selain pengumuman kasus covid 19 pertama di Indonesia. Pengamatan dimulai pada 7 hari sebelum pengumuman yaitu 20 Februari sampai dengan 28 Februari 2020 dan 7 hari setelah pengumuman yaitu 3 Maret sampai dengan 11 Maret 2020.

\section{Jenis dan Sumber Data Penelitian}

Penelitian ini menggunakan sampel perusahan yang bergerak di bidang farmasi yang terdaftar pada Bursa Efek Indonesia (BEI) selama periode pengamatan. Sampel penelitian ini diperoleh dari arsip data yang tersedia pada website resmi BEI www.idx.com. Sampel yang digunakan pada penelitian ini adalah perusahaan pada sektor farmasi. Pemilihan sampel perusahaan pada sektor farmasi sebagai objek penelitian dikarenakan sektor farmasi dianggap sebagai sektor yang memiliki kinerja lebih baik dibanding dengan sektor lain pada masa pandemic covid 19. Kebutuhan akan obat-obatan, vitamin dan alat kesehatan untuk menjaga daya tahan tubuh meningkat pada masa pandemic covid 19. Maka perusahaan pada sektor farmasi dianggap memiliki kinerja yang lebih baik pada masa pandemic covid 19 dibanding dengan sektor lain yang justru kinerjanya menurun dikarenakan berbagai kebijakan pembatasan yang dilakukan pemerintah.

\section{Variabel dan Definisi Operasional}

Penelitian menggunakan variabel pengumuman konfirmasi kasus covid19 di Indonesia dan reaksi pasar saham pada perusahaan sektor farmasi. Covid 19 diukur menggunakan waktu saat Presiden Indonesia Joko Widodo mengumumkan kasus positif covid 19 pertama kali, yaitu pada tanggal 2 Maret 2020. Reaksi pasar diukur menggunakan harga saham dan juga trading volume activity (TVA). Harga saham menggunakan harga saham pada saat penutupan harian, dan variabel TVA menggunakan jumlah 
volume perdagangan saham pada saat penutupan harian. Periode amatan varibel perdagangan saham dimulai pada $\mathrm{h}-7$ sebelum pengumuman konfrimasi kasus covid 19 pertama di Indonesia sampai dengan $\mathrm{h}+7$.

\section{Metode Analisis dan Hipotesisi Penelitian}

Penelitian ini menggunakan pengujian uji beda sampel berpasangan (paired sample t-test). Pengujian ini dipilih untuk mengetahui adanya perbedaan antara dua buah sampel yang berpasangan. Pada penelitian ini data yang diuji ialah harga saham dan volume perdagangan saham (TVA) pada sebelum dan sesudah pengumuman konfirmasi kasus covid 19 pertama di Indonesia. Hasil pengujian akan menunjukkan apakah terdapat perbedaan harga saham maupun perbedaan volume perdagangan antara sebelum dan sesudah pengumuman konfirmasi covid 19 masuk di Indonesia.

\section{Hasil Penelitian}

\section{HASIL PENELITIAN DAN PEMBAHASAN}

Hasil pengujian dengan menggunakan uji beda sampel berpasangan (paired sample t-test) menunjukkan adanya perbedaan harga saham antara sebelum pengumuman konfirmasi kasus covid 19 pertama di Indonesia dengan sesudahnya. Pada hasil pengujian data tabel 2 menunjukkan adanya perbedaan harga saham pada hari ke 5 dan ke 7 . Nilai $p$ value pada hari ke 5 adalah sebesar 0,022 lebih kecil dari 0,05, sehingga terjadi perbedaan harga saham antara sebelum dan sesudah pengumuman kasus covid 19. Nilai $p$ value pada hari ke 7 adalah sebesar 0,040 lebih kecil dari 0,05, sehingga terdapat perbedaan harga saham antara sebelum dan sesudah pengumuman kasus covid 19. Hasil pada tabel 2 tersebut menunjukkan bahwa terdapat adanya perbedaan harga saham pada perusahaan sektor farmasi pada saat sebelum dan sesudah pengumuman kasus covid 19 di Indonesia. Berdasarkan hasil pengujian ini maka dapat disimpulkan bahwa hipotesis $1(\mathrm{H} 1)$ terdukung.

Pengujian yang dilakukan pada volume perdagangan saham (TVA) menunjukkan tidak terjadi adanya perbedaan antara sebelum dan sesudah adanya pengumuman kasus pertama covid 19 di Indonesia. Pada hari ke 5 nilai $p$ value sebesar 0,160 lebih besar dari 0,05 yang menunjukkan tidak terdapat perbedaan pada volume perdagangan saham. Pada hari ke 7 nilai $p$ value sebesar 0,163 lebih besar dari 0,05 yang berarti tidak terjadi perubahan volume perdagangan saham. Hasil ini menunjukkan volume perdaganga saham pada sebelum dan sesudah pengumuman kasus covid $19 \mathrm{di}$ Indonesia tidak terjadi perbedaan. Berdasarkan hasil pengujuan tersebut dapat disimpulkan bahwa hipotesis $2(\mathrm{H} 2)$ ditolak. 


\section{$J A A$}

Vol. 6, No. 1, Oktober 2021

Tabel 2. Hasil Pengujian Paired Sample T-test

\begin{tabular}{lllll}
\hline \multirow{2}{*}{$t$} & \multicolumn{2}{l}{ Harga Saham } & \multicolumn{2}{l}{ Volume Perdagangan Saham } \\
\cline { 2 - 5 } & $\mathbf{t ~ H i t u n g}$ & $\mathbf{p}$ & t Hitung & $\mathbf{P}$ \\
\hline 1 & -1.019 & 0.335 & -0.592 & 0.568 \\
2 & -1.060 & 0.317 & -0.605 & 0.560 \\
3 & -1.352 & 0.209 & -1.210 & 0.257 \\
4 & 0.107 & 0.917 & -1.386 & 0.199 \\
5 & 2.276 & $0.022^{* *}$ & -1.532 & 0.160 \\
6 & 2.055 & 0.070 & -2.008 & 0.076 \\
7 & 3.675 & $0.040 * *$ & -1.518 & 0.163 \\
\hline
\end{tabular}

Keterangan: Perbandingan antara $\mathrm{H}-1$ dengan $\mathrm{H}+1$, dst.

* signifikan pada 0,$01 ; * *$ signifikan pada 0,$05 ; * * *$ signifikan pada 0,001

Sumber: data diolah 2021

\section{Pembahasan}

Hasil pengujian menggunakan paired sample t-test pada penelitian ini didapatkan adanya perbedaan harga saham yang disebabkan pengumuman konfirmasi kasus covid 19 di Indonesia. Setelah pengumuman oleh presiden Indenesia tentang konfirmasi kasus positif covid 19 pertama pada 2 Maret 2020 terjadi perbedaan harga saham pada perusahaan sektor farmasi. Pada gambar 3 dapat dilihat adanya perbedaan harga saham pada perusahaan sektor farmasi.

Pada hasil penelitian menunjukkan perbedaan harga saham yang terjadi mayoritas cenderung mengalami penurunan harga saham. Hal tersebut dapat disebabkan pesimisme masyarakat terhadap kinerja arus kas perusahaan pada kondisi pandemi termasuk pada sektor farmasi. Perusahaan farmasi seharusnya dapat menjadi bagian penting dalam penangan pandemi yang sedang terjadi.

Sampai dengan pengumuman kasus konfirmasi positif covid 19 pertama di Indonesia, perusahaan farmasi belum memperlihatkan tandatanda akan mengembangkan vaksin atau mengeluarkan informasi lain untuk melawan pandemi. Selain itu kebijakan pemerintah yang dinilai masyarakat kurang sigap menanggapi masuknya covid 19 di Indonesia, semakin menurunkan harapan masyarakat terhadap kinerja perusahaan farmasi. Pada kondisi ini masyarakat menilai kinerja perusahaan sektor farmasi sama dengan perusahaan sektor lain yang tidak berdaya saat covid 19 masuk di Indonesia. 
Minimnya ketersediaan informasi tentang kesiapan perusahaan sektor farmasi dalam menghadapi covid 19 yang sudah mulai masuk di Indonesia menjadi salah satu penyebab masyarakat merespon negatif harga saham. Hasil penelitian yang menunjukkan perbedaan harga yang tidak langsung terjadi pada saat hari $\mathrm{H}$ pengumuman kasus covid 19 pertama di Indonesia menunjukkan bahwa masyarakat menunggu perkembangan informasi dari perusahaan maupun kebijakan pemerintah sebelum mengambil keputusan di pasar saham.

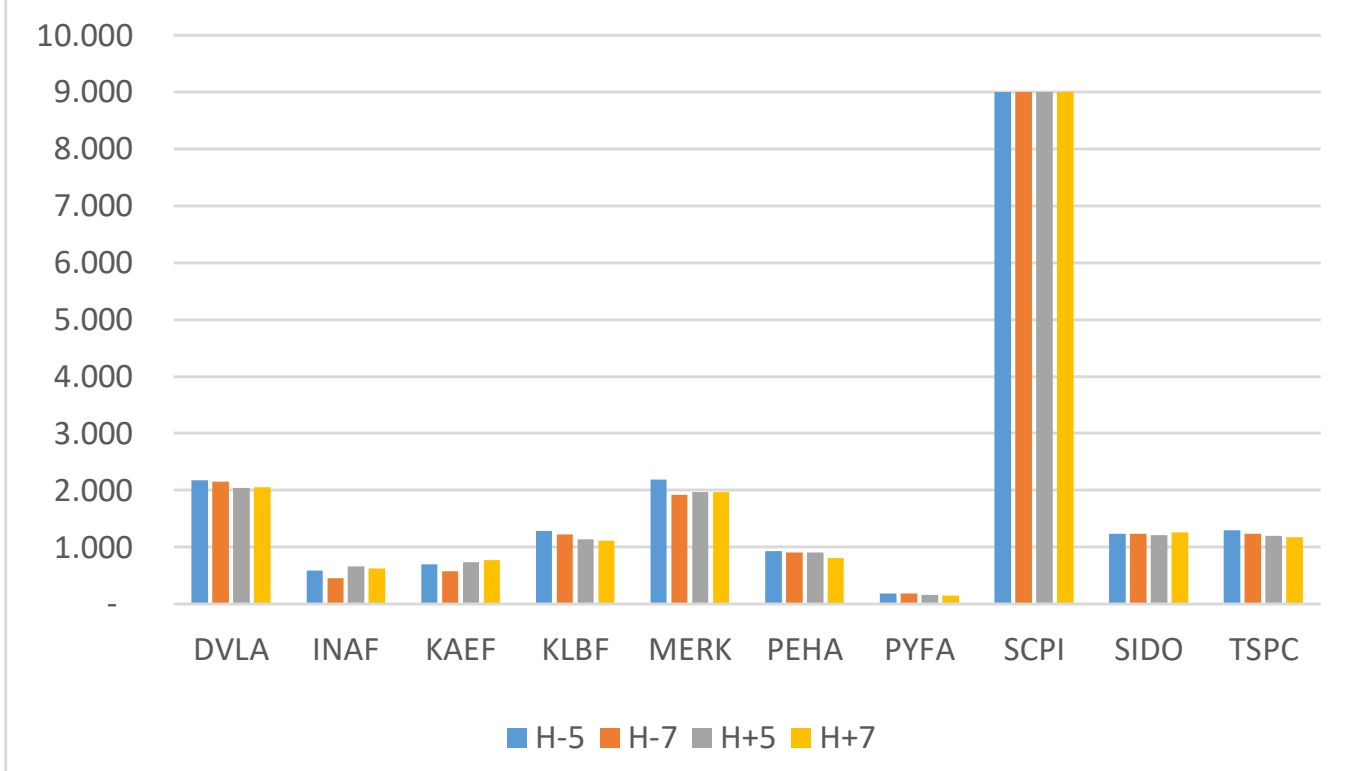

Sumber : Data Diolah 2021

\section{Farmasi}

Gambar 3. Grafik Perubahan Harga Saham Perusahaan

Gambar 3 menunjukkan grafik perbedaan harga saham pada h-5 dan h-7 sebelum pengumuman kasus pertama covid 19 di Indonesia dengan $\mathrm{h}+5$ dan $\mathrm{h}+7$ sesudah pengumuman. Hasil dari 10 sampel perusahaan sektor farmasi sebagian besar menunjukkan penurunan harga saham. Namun demikian terdapat 3 perusahaan sektor farmasi yang menunjukkan peningkatan harga saham setelah pengumuman kasus covid 19, yaitu PT Indofarma Tbk. (INAF), PT Kimia Farma Tbk. (KAEF), dan PT Industri Jamu dan Farmasi Sido Muncul Tbk. (SIDO), sedangkan untuk 6 sampel lainnya mengalami penurunan harga saham, dan satu sampel yaitu PT Merck Sharp Dohme Pharma Tbk (SCPI) tidak mencatatkan adanya aktivitas perdagangan saham. Hasil ini tidak sepenuhnya sejalan dengan hasil penelitian Al-Awadhi et al., (2020) yang menyatakan bahwa perusahaan sektor farmasi memiliki kinerja lebih baik dibanding sektor lainnya, meskipun hasil pengujian menunjukkan hanya 3 perusahaan dari 10 sampel perusahaan yang menunjukkan kenaikan harga saham. Hal tersebut bisa disebabkan karena PT Indofarma Tbk. (INAF) dan PT Kimia Farma Tbk. (KAEF) merupakan Badan Usaha Milik Negara (BUMN), sehingga diharapkan 


\section{DA}

Vol. 6, No. 1, Oktober 2021

terlibat dalam program pemerintah dalam menangani covid 19. Sedangkan PT Industri Jamu dan Farmasi Sido Muncul Tbk. (SIDO) merupakan perusahaan jamu yang produknya sudah popular dikalangan masyarakat.

Hasil pengujuan statistik pada penelitian ini tidak menemukan adanya perbedaan yang signifikan pada volume perdagangan saham. Meskipun terjadi perbedaan pada harga saham namun perbedaan volume perdagangan saham tidak terjadi sebelum dan sesudah pengumuman kasus covid 19 di Indonesia, hal ini menunjukkan bahwa investor memilih menerapkan strategi untuk melakukan hold/ menahan saham yang dimiliki. Investor memilih strategi tersebut dengan tujuan untuk mengamankan nilai aset sahamnya dibandingkan jika melepas atau menjual saham dan mengakui realisasi kerugian atas pelepasan saham.

Pada masa pandemi covid 19 ini yang disertai kebijakan pemerintah dalam pembatasan kegiatan sosial dan ekonomi sehingga menyebabkan ketidakpastian dan volatilitas harga pada pasar saham (Baldwin, 2020). Investor dipaksa untuk mengambil risiko yang lebih besar karena dihadapkan pada situasi pasar saham yang mengalami volatilitas harga saham. Namun demikian hasil penelitian ini menunjukkan bahwa investor lebih memilih untuk menahan kepemilikan saham pada perusahaan sektor yang dimiliki yang dibuktikan dengan tidak terjadi perbedaan volume perdagangan antara sebelum dan sesudah pengumuman kasus covid 19. Hasil ini sejalan dengan hasil penelitian Khabibah, et al (2021)

Investor melakukan aksi menahan kepemilikian saham sektor farmasi dimungkinkan karena pada masa pandemi beberapa perusahaan mengalami kondisi yang berbeda. Penelitian Al-Awadhi et al., (2020) menyatakan perusahaan pada sektor teknologi informasi dan menufaktur farmasi memiliki kemungkinan kinerja lebih baik dibanding perusahaan pada sektor lain. Selain itu para investor kemungkinan menerapkan strategi wait and see untuk melihat perkembangan kondisi kasus covid 19 di Indonesia sehingga tidak terburu-buru untuk melepas kepemilikan saham.

\section{SIMPULAN}

Penelitian ini menguji perbedaan harga saham dan volume perdagangan saham perusahaan sektor farmasi sebelum dan sesudah pengumuman kasus covid 19 pertama di Indonesia. Berdasarkan hasil pengujian dengan menggunakan pengujian uji beda sampel berpasangan (paired sample t-test) didapatkan hasil terjadi perbedaan harga sebelum dan sesudah pengumuman kasus covid 19 pertama di Indonesia yaitu pada hari ke 5 dan ke 7, namun demikian tidak terjadi perbedaan pada pengujian volume perdagangan.

Penelitian ini dapat dilanjutkan untuk menguji pengaruh covid 19 pada pasar saham di sektor yang lainnya. Selain itu perlu dilakukan penelitian lebih dalam terkait dampak covid 19 terhadap kinerja saham perusahaan pada jangka panjang. 
Kartika Pradana S \& Nibras Anny K: Reaksi Pasar Saham Perusahaan Farmasi Sebelum.....

\section{DAFTAR PUSTAKA}

Al-Awadhi, M. A., Al-Saifi, K., \& Al-Awadhi, A. (2020). Death and Contagious Infectious Diseases: Impact of the COVID-19 Virus on Stock Market Returns. Ournal of Behavioral and Experimental Finance, (100326).

Baker, S. R., Davis, S. J., Kost, K. J., Sammon, M. C., \& Bloom, N. (2020). THE UNPRECEDENTED STOCK MARKET IMPACT OF COVID-19. Covid Economics: Vetted and Real-Time Papers, 1, 3.

Baldwin, R. (2020). Thinking Ahead about the Trade Impact of COVID-19. In R. Baldwin \& B. Weder (Eds.), Economics in the Time of COVID-19. Mauro: CEPR Press.

Camba, A. L., \& Jr, A. C. C. (2020). The Effect of COVID-19 Pandemic on the Philippine Stock Exchange , Peso-Dollar Rate and Retail Price of Diesel. The Journal of Asian Finance, Economics and Business, ス10), 543-553. https://doi.org/10.13106/jafeb.2020.vol7.no10.543

Chen, C. D., Chen, C. C., Tang, W. W., \& Huang, B. Y. (2009). The positive and negative impacts of the SARS outbreak: A case of the Taiwan industries. The Journal of Developing Areas, 43 (1), 281-293.

Dewi, I. G. A. A. O., \& Rama, G. R. B. (2019). Analisis Abnormal Return, Trading Volume Activity dan Foreign Capital Inflow Sebelum dan Sesudah Pemilihan Presiden dan Pemilihan Legislatif Tahun 2019 (Studi Pada Perusahaan Anggota Indeks Kompas100 Di Bursa Efek Indonesia). Dewi, I.G.A.A.O., Rama, G. R. B, 4(2), 204-220.

Fama, E. F. (1970). Efficient Capital Markets: A Review of Theory and Empirical Work. The Journal of Finance, 25 (2), 383-417.

Funck, M., \& Gutierrez, J. (2018). Has Ebola Infected The Market: A Contagious Reaction to A (Media) Health Care Crisis? Ournal of Business Strategies, 35 (2), 55-75.

Kamaludin, K., Sundarasen, S., \& Ibrahim, I. (2021). Covid-19 , Dow Jones and equity market movement in ASEAN-5 countries: evidence from wavelet analyses. Heliyon, (November 2020), e05851. https://doi.org/10.1016/j.heliyon.2020.e05851

Khabibah, N. A., Rani, U., \& Suryatimur, K. P. (2021). COVID-19 DAN REAKSI PASAR PERUSAHAAN MAKANAN DAN MINUMAN DI INDONESIA. Jurnal Kajian Akuntansi, 5(1), 113-126.

Ross, A. S. (1977). The Determination of Financial Structure: The IncentiveSignalling Approach. The Bell Journal of Economics, 8 (1), 23-40.

Sohrabi. (2020). World Health Organization declares global emergency: A review of the 2019 novel coronavirus (COVID-19). International Journal of Surgery, 76, 71-76.

Yang, Y., Peng, F., \& Wang, R. (2020). The deadly coronaviruses: The 2003 SARSpandemic and the 2020 novel coronavirus epidemic in China. Journal of Autoimmunity, 102434.

Ying, T, Y., Ain, Ul, Q., Yasmeen, A., \& M.S, R. (2019). Stock Investment 


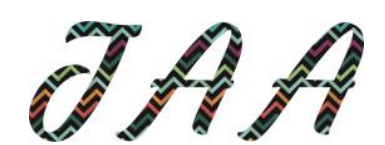

Vol. 6, No. 1, Oktober 2021

and Excess Returns: A Critical Review in the Light of the Efficient Market Hypothesis. Journal of Risk and Financial Management, 12, 122.

Zhang, Y., Song, W., Shen, D., \& Zhang, W. (2016). Market reaction to internet news: Information diffusion and price pressure. Economic Modelling, 56, 43-49. 